\title{
THE JURISDICTIONAL IMMUNITY OF FOREIGN SOVEREIGNS
}

CourTs of every nation recognize the immunity ${ }^{1}$ of a foreign sovercign. ${ }^{2}$ This limitation upon their jurisdiction originated in an era of personal sovereignty when the domestic ruler was above the law. ${ }^{3}$ Failure to grant similar treatment to a foreign prince indicated either hostility or superiority. In order to avoid friction that might result from offending the dignity of another sovereign, the local state exempted him from its jurisdiction. ${ }^{4}$ The claims of individuals were sacrificed in the national interest.

In The Exchange, ${ }^{5}$ Chief Justice Marshall firmly emplanted foreign sovereign immunity in American law. American owners of the schooner Exchange sued to recover the vessel while it lay in Philadelphia harbor. It had been seized abroad by Napoleonic agents, who converted it into a French warship. Plaintiff's claimed that " $[\mathrm{e}]$ very person ... who is entitled to property brought within the jurisdiction of our courts, has a right to assert his title in those

1. This comment is concerned primarily with the immunity from Amcrican judicial jurisdiction which foreign sovereigns enjoy for themselves and their property. Jurisdictional immunity should be distinguished from the immunity from execution granted to the property of foreign sovereigns. For brief treatment of the latter, see notes 111-116 infra and accompanying text.

For the views of other countries on the jurisdictional immunity of foreign states, sec Draft Convention of the Competence of Courts in Regard to Forcign States, 26 AM. J. INT'L L. 451, 527-540, 572-645 (Supp. 1932) (hereinafter cited as HaRvard ResenkCH); Lauterpacht, The Problem of Jurisdictional Immunities of Forcign States, 28 Brit. Y.B. INT'L L. 220, 250-272 (1951) (hereinafter cited as LAUTERPACHT). For discussion of the various means by which a state may be held to waive this immunity, see HaRvarv RESEARCH, stpra at 508-527, 540-572; Dickinson, Waiver of State Immmuity, 19 AM. J. INT'L L. 555 (1925).

2. The terms "sovereign," "government," and "state" are used synonymously in this comment.

"It is unanimously admitted that the courts of one State have no jurisdiction over an" other State when the foreign State is sued for acts accomplished by it in the exercise of its sovereign rights." 9 Matsuda Report on Competence of Courts in Regard to Foreign States (Committee of Experts, Progressive Codification of International Law, League of Nations) 6 (1927) ; also cited in 22 Ax. J. INT'L L. 127 (Supp. 1928).

3. "Historically the rule may be traced to a time when most States were ruled by personal sovereigns who, in a very real sense, personified the State-'L'Etat, c'est moi.'" HaRvard Research, supra note 1, at 527. The common law maxim that the King can do no wrong expressed the absolute nature of sovereign power. Its roots lay in the Roman idea of a personal, imperial despot. Sanborn, The Immunity of Merchant Vessels When Owned By Foreign Governments, 1 St. JoHn's L. Rev. 5 (1926). See Feather v. The Queen, 6 B. \& S. 257, 295 (1865) ; LAUTERPACHT, supra note 1, at 232.

4. In this era of personal rule, "influenced by the survival of the principle of feudalism, the exercise of authority on the part of one sovereign over another inevitably indicated either the superiority of overlordship or the active hostility of an equal. The peaceful intercourse of States could be predicated only on the basis of respect for other sovereigns." HaRvard ResearCH, supra note 1, at 527.

5. Schooner Exchange v. McFaddon, 7 Cranch 116 (U.S. 1812). 
courts. ..." But the Supreme Court found that until the United States exercised its complete territorial power "in a manner not to be misunderstood," it promised impliedly to exempt visiting sovereigns from its jurisdiction. And the Court held that the immunity of the sovereign person extended to the sovereign's public armed vessels. To hold otherwise, it said, would affect the power and degrade the dignity of the foreign sovereign. ${ }^{8}$

The doctrine of foreign sovereign immunity announced in The Exchange assumes great importance in the twentieth century. ${ }^{9}$ The entry by governments into many previously private pursuits ${ }^{10}$ and the rapid expansion of international intercourse have created many new occasions for its application. And courts, which have become increasingly sensitive to the impact of foreign affairs, have applied the doctrine to these new situations in order to avoid international friction. ${ }^{11}$

On the other hand, growing recognition of individual rights militates against a principle that denies redress for wrongs done to private persons. ${ }^{12}$ Recon-

6. Id. at $1+6-7$.

7. Id. at 146 .

8. Id. at 144. The Chief Justice stated that the foreign ministers and the troops in transit of a foreign prince were also entitled to immunity. Id. at 13s-9.

9. For discussion of the doctrine's developments, see Riesenfeld, Sorcrcign Inmuturity of Foreign Vessels in Anglo-American Laal: the Ea'olution of a Legal Doctrinc, 25 MIn:. L. Rev. 1 (1940).

10. The Supreme Court acknowledged this in The Pesaro, 271 U.S. 562 (1926), where it granted immunity to a merchant ship owned and operated by the Italian Government. In discussing the failure of The Excliange to include such vessels within the privileged category, the Court said "the omission is not of special significance, for in 1812, when the decision was given, merchant ships were operated only by private owners, and there was little thought of governments engaging in such operations. That came much later." Id. at 573. See also The Maipo, 259 Fed. 367 (S.D.N.Y. 1919).

11. See, e.g., Berizzi Bros. v. The Pesaro, 271 U.S. 562 (1926) (immunity of government merchant vessel) ; The MIaipo, 259 Fed. 367 (S.D.N.Y. 1919) (same) ; French Republic v. Board of Supervisors, $200 \mathrm{Ky} .18,252$ S.W. 124 (1923) (immunity from tasation of government tobacco). This concern for international amity is often summarized by the term "comity" See Guaranty Trust Co. v. United States, 304 U.S. 126, 134 (1937) ; The Cristina, [1938] A.C. 485, 518; Riesenfeld, supro note 9, at 3 n.12.

12. Most commentators agree that immunity must somehow be curbed rather than extended, in keeping with the trend toward achievement of "the rule of law." See the au= thorities cited in Eishop, New Unitcd States Polioy Limiting Soacrign Imminnity, 47 Axr. J. INT'L L. 93, 96 n.13 (1953). Professor Lauterpacht has stated that modern developments in the social and economic sphere represent "a challenge to the prerugatives of the sovereign state which denies to th individual legal remedies for the vindication of his rights as against the state in the matter both of cuntract and tort. . . ." Lauransacur, 28 BRIT. Y.B. INT'L L. 220 (1951). Another writer has said that the state slould be as subject to the law as is the individual, for the tort of a government official "must shosl: the collective conscience of the community as much as the tort of any cther individual." Sanborn, sapra note 3, at 8-9. See also Jessup, Has the Suprome Court Albdicalcd One of Its Fanctions?, 40 Axr. J. INT'L L. $16 \mathrm{~S}$ (1946).

Judicial concern for individual rights is more often counterbalanced by fear of embarrassing the conduct of foreign relations through denial of immunity. See text at notes 
ciliation of the policy of avoiding international friction with the policy of enhancing individual satisfactions presents a challenge which the courts have failed to meet. ${ }^{13}$

\section{The Traditional American Approach}

American courts have followed the "absolute theory" of immunity, which grants immunity in all cases where a sovereign is defendant. ${ }^{14}$ But they have attempted to limit the applicability of this theory by restricting their definition of what constitutes suit against a sovereign. ${ }^{15}$ In actions in rem against sovereign property, immunity has been denied where the foreign government is not in possession of the property. And in suits against a sovereign agency, immunity has been denied where the agency is a corporation.

\section{Ships}

Almost all in rem actions brought against foreign sovereign property are in admiralty, and the most significant decisions in the evolution of the sovereign immunity doctrine have concerned ships. Traditionally, a ship has received immunity only if it is in possession of a foreign government ${ }^{10}$ when suit is

38-56 infra. But enlightened judges occasionally acknowledge the undesirable consequences of granting immunity. "The immunity of the sovereign may well become a serious injustice to the citizen, if it can be claimed in the multitude of cases arising from governmental activities which are increasing so fast." Gould Coupler Co. v. U.S.S.B.E.F.C., 261 Fed. 716, 718 (S.D.N.Y. 1919). See also Republic of China v. Nat. City Bank, 208 F.2d 627, 630 (2d Cir. 1953) ; The Pesaro, 277 Fed. 473, 481 (S.D.N.Y. 1921). And some courts recognize that immunity provides sovereign commercial instrumentalities with an unfair advantage over private competitors. See the opinion of Lord Matugham in The Cristina [1938] A.C. $485,521$.

For the nineteenth century view exalting sovereign immunity, see the opinions of Justice Holmes in The Western Maid, 257 U.S. 419 (1921); Kawananakoa v. Polyblank, 205 U.S. 349, 353 (1907). In Davis v. Pringle, 268 U.S. 315, 318 (1925), Justice Holmes recognized that "public opinion as to the peculiar rights and preferences due to the savereign has changed."

13. For recognition of this judicial dilemma, see Deák, The Plea of Sovercign Immunity and the New York Court of Appeals, 40 CoL. L. REv. 453, 464 (1940) ; Ricsenfeld, supra note 9, at 65 .

14. 26 Dep't State Bull. 984 (1952). See Fensterwald, Sovercign Imumunily and Soviet State Trading, 63 HARv. L. REv. 614, 617-18 (1950); LAuTERPACuT, supra note 12, at 268; Friedmann, The Grozeth of State Control Over the Individhal, and its Effect upon the Rules of International State Responsibility, 19 BRIT. Y.B. INT'L L. 118, 124 (1938).

15. See Fensterwald, sitpra note 14 , at 618 et seq.

16. Mexico v. Hoffman, 324 U.S. 30 (1945) ; The Navemar, 303 U.S. 68 (1938). Sce note 18 infra for some of the lower court cases in a long line tracing back to Long $v$. The Tampico, 16 Fed. 491. (S.D.N.Y. 1883). In that case the requirement of foreign governmental possession was arrived at by analogizing to the Supreme Court's doctrine with respect to the immunity of United States property. Id. at 496. 
filed. ${ }^{17}$ "Title" in the government has not been sufficient., ${ }^{18}$ despite its vigorous representations of immunity. ${ }^{19}$ The rationale offered for this distinction is that jurisdiction over the ship is not jurisdiction over its sovereign in the absence of "possession."

But, because of its ambiguity, "possession" is a most unsatisfactory standard for deciding questions of immunity." For example, an executive decree of the Spanish Republican Government purported to requisition the steamship Navcmar $^{22}$ while it was on the high seas. Spanish consuls in Argentine ports en-

17. The Katingo Hadjipatera, 40 F. Supp. 546 (S.D.N.Y.), alfd, 119 F.2d 1022 (2d Cir. 1941) (immunity denied where the vessel was lihelled prior to the date for which possession was scheduled).

18. E.g., The Beaton Park, 65 F. Supp. 211 (W.D. Wash. 1946); The Ljubiea Matkovic, 49 F. Supp. 936 (S.D.N.Y. 1943); The Uxmal, 40 F. Sunp. 35 (D. Mass. 1941); The Johnson Lighterage Co., 231 Fed. 365 (D.N.J. 1916). Also see cases citcd note 16 supra.

Indeed, "title" does not even appear to be a prerequisite to immunity in American courts. They have treated vessels whose use was requisitioned in the same manner as those owned by foreign governments. "Possession" has been required in buth classes of cases. See The Navemar, 303 U.S. 68 (1938); The Attualita, 238 Fcd. 909 (4th Cir. 1916); The Katingo Hadjipatera, 40 F. Supp. 546 (S.D.N.Y.), af'd, 119 F.2d 1022 (2d Cir. 1941).

English courts take a different view of the significance of "pussession" "title" and "requisition," granting immunity when any one of the three is found in a fureign government. See the opinion of Lord Wright in The Cristina, [1938] A.C. 485, 507.

It is, of course, realized that words such as "title" and "possession" are highly ambiguous. They refer not to facts but to legal consequences, i.e., oficial responses to facts. For illustration, see text at notes $21-24$ infro.

19. For the determined efforts of the Spanish Republic to cbtain immunity for one of its ressels, see The Navemar, 17 F. Supp. 495 , 647 (E.D.N.Y. 1936); 18 F. Supp. 153 (E.D.N.Y. 1937) ; 90 F.2d 673 (2d Cir. 1937) ; 303 U.S. 6S (1938) ; 24 F. Supp. 495 (E.D. N.Y. 1938); 102 F.2d 444 (2d Cir. 1939). Sce also nutes $22-24$ infra and accumpanying text.

20. "Property does not necessarily become a part of the sovereignty bscause it is owned by the sovereign. To make it so, it must be deveted to the publis use, and must be employed in carrying on the operations of the government." Waite, C.J. in The Fidelity, 8 Fed. Cas. 1189 , 1191, No. 4,758 (C.C.S.D.N.Y. 1879). See The Annette; The Dors, [1919] P. 105, 111, where the court said: "If it is not in possession, the C. urt interferes with no sovereign right of the government by arresting the vessel, nor dies it, by arresting the vessel, compel the governmont to sulmit to the jurisdiction or to ahandon its possession."

21. See the concurring opinion of Justice Franlfurter in Mexico v. Hofiman, 327 U.S. 30,38 (1945). "[P]ossession is teo tenutous a distinction on the basis of which to differesttiate between foreign government-owned vessels engagcd merely in trade that are immune from suit and those that are not. Possession, actual or constructive, is a legal concent full of pitfalls. Even where only private interests are involved, the determination of pussessin, as bankruptcy cases, for instance, abundantly prove, engenders much coniusion and conflict. Ascertainment of what constitutes possession or where it is, is too suitle and precarious a task for transfer to a field in which intcrnational interests and susceptibilities are involved." Id. at 39-40. See also Riesenfeld, Suarcign Immonsily of Forcijn I"cssels in Anglo-Anerican Law: the Erolution of a Lcgal Doctrine, 25 Afras. L. Rev. 1, 55-6 (1910).

22. The Naremar, 303 U.S. 68 (1938). 
dorsed on both the ship's roll and its register that it had become state property. And its master obeyed consular orders to notify Madrid that the Consul General had authorized him to sail to New York. Yet, when the vessel was subsequently libelled in the United States and the Spanish Ambassador claimed immunity, the Supreme Court denied that these acts met the test of possession. ${ }^{23}$ That test was held to require ". . . some act of physical dominion or control . . . or at least some recognition on the part of the ship's officers that they were controlling the vessel and crew in behalf of their government."24

And even if "possession" were not so tenuous, its use as a distinguishing factor would still be undesirable. The indignity and the inconvenience of submitting to the local jurisdiction when the foreign state has only title are often no less than when it has possession, ${ }^{25}$ particularly since "possession" need not be physical. ${ }^{26}$ The need for immunity, if any, would seem equal in both instances.

Furthermore, basing immunity on "possession" invites states to deprive private parties of their remedies by resort to readily available devices. For instance, it would probably suffice to place a junior naval officer on a merchant vessel. ${ }^{27}$ And, on the authority of The Navemar, ${ }^{28}$ mere symbolic recognition of government possession by the ship's officers might meet the Supreme Court's test. ${ }^{29}$

\section{Agencies}

Traditional doctrine grants immunity to government agencies, commissions, and other instrumentalities unless they have corporate personality ${ }^{30}$ The

23. Id. at 75-6. The Court reversed the Second Circuit, which considered these facts to be evidence of possession and control and which held that they constituted at least constructive possession. The Navemar, 90 F.2d 673 (2d Cir. 1937).

24. The Navemar, 303 U.S. $68,75-6$ (1938). It is difficult to understand how the facts of this case failed to satisfy the Court's test.

25. The Navemar provides an example. See note 19 supra; and see notes 22-24 supra and accompanying text.

26. See text at note 24 supra. Although Mexico v. Hoffman, 324 U.S. 30 (1945), is often cited for the proposition that possession must be "actual," the Court did not purport to decide the nature of the possession requisite to immunity. The question before it was whether or not mere title in the government was sufficient to warrant immunity. Sec text at notes 49-51 infra. The Court gave no indication of altering the test of possession laid down in The Navemar. On the contrary, it relied on that decision as authority for its holding. $I d$. at 37 . It is noteworthy that Justice Frankfurter in his concurring opinion attacked the Court's use of possession, actual or constructive, as a test of immunity. Id. at 40 .

27. Justice Frankfurter, concurring, in Mexico v. Hoffman, 324 U.S. 30, 40 (1945). He added, somewhat cryptically, that "certainly, the terms of the financial arrangement by which the commercial enterprise before the Court is carried out can readily be varied without much change in substance to manifest a relation to the ship by Mexico which could not easily be deemed to disclose a want of possession by Mexico." Ibid.

28. See text at note 24 supra.

29. See note 26 supra.

30. For cases where immunity was granted to unincorporated government instrumen- 
rationale for thus distinguishing between incorporated and unincorporated government agencies appears to be based upon the corporation's conceptually independent existence. ${ }^{31}$ Hence, a suit against the corporation is not usually considered to be a suit against the government which it serves.32

But non-incorporation is just as unsatisfactory a criterion for granting immunity as is "possession." Any affront to sovereign prestige or interference with government operations would appear to be the same whether judicial authority is exercised over incorporated or unincorporated agencies. ${ }^{33}$ And this test permits no distinction between cases where an agency's immunity may

talities, see, e.g., Oliver Trading Co. v. Mfexico, 5 F.2d 659 (2d Cir.), aff'd, 264 U.S. 440 (1924) ; French Republic v. Board of Supervisors, 200 Ky. 18, 252 S.W. 124 (1924); Mason v. Intercolonial Ry. of Canada, 197 MIass. 349, 83 N.E. 876 (1908). Cf. Dexter \& Carpenter v. Kunglig Jarnvagsstyrelsen, 43 F.2d 705 (2d Cir. 1930) (immunity from execution granted to the property of Swedish national railread). For cases where immunity was denied because the government agency was a corporation, see c.g., Amtorg Trading Corp. v. Commissioner, 65 F.2d 583 (2d Cir. 1953); Amtorg Trading Corp. v. United States, 71 F.2d 524 (C.C.P. 1934); The Uxmal, 40 F. Supp. 258 (D. Míass. 1941) ; United States v. Deutsches Kalisyndikat Gesellschaft, 31 F.2d 199 (S.D.X.X. 1929) ; Coale v. Société Co-operative Suisse des Charbons, 21 F.2d 180 (S.D.N.Y. 1921). Contra: In re Investigation of World Arrangements, 13 F.R.D. 280 (D.D.C. 1953); Bradford v. Dir. Gen. of Railroads of Mexico, 278 S.WW. 251 (Tex. Civ. App. 1925). See Article 26 of the Harvard Researce, 26 Aar. J. Ixr' L. 451 (Supp. 1932) : "A State need not accord the privileges and immunities provided for in this Convention to such juristic persons as corporations or associations for profit separately organized by or under the authority of another State, regardless of the nature and extent of governmental interest therein or control thereof." Id. at 716.

The criterion of non-incorporation in cases of foreign sovereign immunity was burrowed from case law concerning the immunity of agencies created by states of the Unitcd States. See Briscoe v. Bank of Kentucky, 11 Pet. 257 (U.S. 1837) ; Bank uf Kentucly v. Wister, 2 Pet. 318 (U.S. 1829) ; Bank of United States v. Planters' Bank of Ga, 9 Wheat. 904 (U.S. 1824).

31. See, e.g., United States v. Deutsches Kalisyndikat Gesellsehaft, 31 F.21 190, 202 (S.D.N.Y. 1929) ; Coale v. Société Co-operative Suisse des Charbons, 21 F.2d 180, 181 (S.D.N.Y. 1921) ; Ulen v. Bank Gospodarstwa Krajowego, 261 App. Div. 1,7, 24 X.Y.S.2.1 201,206 (2d Dep't 1940). "The courts will not usually tear aside the corpurate veil, baing for the most part eager to avoid the inequitable consequences of swereignty. A distinetion is therefore drawn between the corporate entity and the state, even tisugh the lattur owns all the stock." Jessup and Deak, Dexter \& Carpenter, Inc. I. Ktunglisy Jorr:adystyrelseiz et al, 25 Axr. J. INT'L L. 335, 338 (1931).

32. "A suit against a corporation is not a suit against a government merely becausa it has been incorporated by direction of the government, and is used as a governmental a 36 int, and its stock is owned solely by the government." United States v. Deutsches Kalisyndikat Gesellschaft, 31 F.2d 199, 202 (S.D.N.Y. 1929).

33. See In re Investigation of World Arrangements, 13 F.R.D. 280 (D.D.C. 1952), where the court deviated from the general rule and granted immunity to the Anglo-Iranian Oil Co., a government-controlled corporation. It found that the policy iavoring s. ereign immunity in other circumstances was equally applicable here. "There is the same necessity for reciprocal rights of immunity, the same feeling of injured pride if jurisdiction is sought to be exercised, the same risk of belligerent actiun if government property is subsequently seized or injured." Id. at 291. Professor Hyde has stated that: "When a suit against an entity or commission or agency is in substance a suit against a forcign 
be important to its government and cases where it would be of little concern. ${ }^{84}$ Moreover, a standard which emphasizes form lends itself to evasion. With no great difficulty, a state may create a variety of entities which resemble corporations and which may yet retain immunity. ${ }^{35}$

Thus, judicial efforts to restrict the applicability of the absolute theory reveal a highly conceptual approach which fails to satisfy either of the policies competing for consideration. ${ }^{36}$ This approach does not always avoid embarrassment to foreign relations, nor does it aid many individuals injured by other

State on whose behalf and by whose authority it acts, a reason for exemption from the local jurisdiction is seen." 1 Hyde, International LAw 814 (2d Rev. ed. 1945).

34. See, e.g., In re Investigation of World Arrangements, supra note 33. The court found that the Anglo-Iranian Oil Co., although a corporation, was fulfilling a function vital to the security of Great Britain by supplying that nation with oil for its defenses against aggression. Id. at 290-1.

35. See Riesenfeld, Sovereign Immumity of Foreign Vessels in Anglo-American Law: the Evolution of a Legal Doctrine, 25 MinN. L. REv. 1, 56 n.215 (1940), where the author discusses this possibility with respect to ships: "The legal forms in which a state can own and operate a vessel are multifold. It may be the sole owner of all the stock of an ordinary private corporation; it may incorporate specifically for that purpose, but the corporate structure being similar to an ordinary corporation; it may set up completely new forms of public corporations for that purpose; finally, it may create just 'scparatc governmental agencies or departments." "See also Friedmann, The Growth of Stalc Control Over the Individual, and its Effect upon the Rules of Intcrnational Responsibility, 19 BRIT. Y.B. INT'L L. 118, 130 (1938).

36. Even sophisticated courts tend to lose sight of some of the policy considerations in sovereign immunity problems. See, e.g., Sullivan v. Sao Paulo, 122 F.2d 355 (2d Cir. 1941). There, a private citizen sued two states of the United States of Brazil for principal and interest on bonds issued by defendants, attaching their New York bank accounts. Brazil claimed immunity for these funds because judicial process would interfere with its regulation of foreign exchange to be used by the states to meet defaulted foreign obligations. The Second Circuit declined to grant immunity on this ground because it would immunize "property in this country from attachment for a debt due here merely on the assertion of a foreign sovereign, not of title or a recognized property interest, but of a plan for rationing foreign exchange." Id. at 359. But it did grant immtnity on the ground that the Brazilian states occupy in Brazil a status similar to that of our own states in the United States. Since these latter enjoy immunity in cases not covered by the Eleventh Amendment, Judge Clark said it was not only "natural and reasonable," but also necesstry for friendly international intercourse to grant the Brazilian states a similar privilege. Ibid.

The premise that amicable relations require the United States to grant immunity to foreign states and their subdivisions in situations where it asserts immunity for itself and its subdivisions seems valid. See notes $96-7$ infra and accompanying text. But rejection of the rationale upon which Brazil claimed immunity sets a poor precedent for cases where equality of treatment would not require immunity. Few matters are more important to the modern nation than regulation of the public debt and control of foreign exchange. Yet the Second Circuit's test would subject such matters to judicial process whenever the con1stitutional position of a foreign political subdivision is unlike that of our own states. $I d$. at 360 . Concern for foreign relations would seem to require a less fortuitous approach than this. 
governments. If international expediency were the sole standard, immunity would be granted whenever a foreign state claimed it. For the denial of immunity serves to embarrass that state whether or not its claim is justified according to traditional technicalities. If maximization of individual satisfactions were the only consideration, immunity would be denied in every case. Traditional American doctrine does not represent a functional compromise between these logical extremes. ${ }^{37}$

\section{Executive Predodinance and Its Imirlications}

In a series of opinions from 1938 to 1945 , $^{38}$ the Supreme Court introduced a period of transition which has not yet terminated in a clear and rational doctrine of sovereign immunity. The Court reemphasized the importance of avoiding international friction. And, in order to implement this policy, it stated that courts, in determining questions of immunity, should defer to "the department of the government charged with the conduct of our foreign relations." 39 The implications of executive predominance are not yet certain.

In upholding the district court's refusal to be bound by the Spanish Ambassador's allegations of immunity in The Navemar, ${ }^{10}$ the Court declared by way of dictum that "[i]f the claim is recognized and allowed by the esceutive branch of the government it is then the duty of the court to release the vessel. . .." 41 But it held that, since the State Department had declined to

37. For a similar conclusion, see Fensterwald, Sozcriga Immusily and Sorict Statc Trading, 63 Harv. L. Rev. 614, 620 (1950). The impolitic nature of this traditiunal approach is most vividly illustrated by cases where private litigants were denied aceess to the courts in order to preserve friendly relations with a government at war with the Cnitci States, Telkes v. Hungarian National Museum, 265 App. Div. 192, 38 N.X.S.2d 419 (1st Dep't 1942) ; with a government no longer in existence, Nankivel v. Omsl All-Russian Government, 237 N.Y. 150, 142 N.E. 569 (1923) ; and with a government not recomized by the United States, Wulfsohn v. Russian Socialist Federated Soviet Republic, 234 A.Y. 372,138 N.E. 24 (1923).

38. The Navemar, 303 U.S. 6S (193S) ; Ex Parte Peru, 318 U.S. 578 (1943); Mexicu v. Hoffman, $32+$ U.S. 30 (1945).

39. Mexico v. Hoffman, 324 U.S. 30,35 (1945) ; Ex Parfe Peru, 318 U.S. 578, 53 (1943).

40. 303 U.S. 68 (1938). See notes $22-4$ supra and accompanying text.

41. The Navemar, 303 U.S. 6S, 74 (1938) (emphasis supplied). A forcign state that wishes to assert immunity may do so by appearing in cuurt for that purguce or 1 y datating the State Department. Both methods are often employed in the same ears. What State Department aid is requested, the Department may or may nut ta'ie actinn. Whon it chooses to act, it usually transmits the request of the foreign government alung with its own statement to the Attorney-General, who then directs the district attorncy to pressit

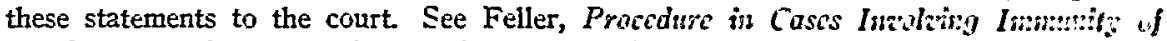
Fareign States inz Courts of the United States, 25 AM. J. Isriz L. 83 (1931).

Prior to The Naz'enar, the State Department's reactions to requests for immunit: ranged from express disapproval of the claim, to inaction, to bare certification of the state"s status as a recognized sovereign, to a request for respectful consideratiun of the surerigris claim, to acceptance of the truthfulness of the facts asserted by the forcign state, to recug- 
intercede in behalf of the Spanish Republic, the question was open to judicial inquiry. ${ }^{42}$

In Ex Parte Pern ${ }^{43}$ the Court dispelled doubts about the meaning of its Navemar dictum by holding that executive "recognition and allowance" constitutes a "conclusive determination" requiring courts to surrender jurisdiction. ${ }^{44}$ It issued a writ of prohibition to the district court, which had refused to release a Peruvian vessel despite "recognition and allowance." Chief Justice Stone stated that judicial deference to executive action was ". . founded upon the policy ... that our national interest will be better served in such cases if the wrongs to suitors, involving our relations with a friendly power, are righted through diplomatic negotiations rather than by the compulsion of jutdicial proceedings." 45

This doctrine of "recognition and allowance" limited the applicability of traditional criteria such as "possession" and non-incorporation, but it did not render them inoperative. In Ex Parte Peru the Court was careful to repent that, in the absence of executive approval of immunity, courts were free to decide the jurisdictional question. ${ }^{46}$

\section{Mexico v. Hoffman}

But Mexico v. Hoffman ${ }^{47}$ has cast doubt upon whether or not these traditional tests retain any contemporary vitality. The owner of an American fishing vessel libelled a merchant ship whose title was in the Mexican Government. Mexico asserted immunity and persuaded the State Department to file

nition of the validity of the claim, to an affirmative demand for dismissal of the suit. Sce Lyons, The Conclusiveness of the 'Snggestion' and Certificate of the American State Department, 24 BRIT. Y.B. INT'L L. 116 (1947). Judicial treatment of these various utterances fluctuated, but, until The Navemar, the courts always retained at least verbal independence of the executive with respect to immunity.

The Supreme Court's dictum in Navemar, providing for automatic dismissal of a stit upon executive "recognition and allowance," added to the confusion surrounding the interpretation and the significance of State Department communications, For a classic example, see Sullivan v. Sao Paulo, 36 F. Supp. 503 (E.D.N.Y.), aff'd, 122 F.2d 355 (2d Cir. 1941), the substantive aspects of which are discussed in note 36 supra. See also Detik, The Plea of Sovereign Immunity and the New York Court of Appeals, 40 CoL. L. REv. 453 (1940).

42. The Navemar, 303 U.S. 68 (1938). The Department refused to take any action whatsoever in the case, advising the Ambassador of his Government's rights to appear directly before the court to make its plea. $I d$. at 71 .

43. 318 U.S. 578 (1943).

44. Ex parte Peru, 318 U.S. 578, 589 (1943). This decision cleared up much of both the procedural and the substantive confusion compounded by The Navemar. The Court's emphasis upon "recognition and allowance" gave these words the status of a formula. And its holding left no uncertainty as to its view that executive use of this formula would bind the courts on questions of law as well as on questions of fact.

45. Ibid.

46. Id. at 587-8.

47. 324 U.S. 30 (1945). 
two "suggestions" with the court, but neither "suggestion" purported to "recognize and allow" the claim.48 The district court found that the ship was in possession of a private company and denied immunity. 10 After the Ninth Circuit affirmed, ${ }^{50}$ certiorari was granted to decide whether or not, in the absence of government possession, Mexico's title to the ship was sufficient to warrant immunity. The Court affirmed the decisions below, holding that "the overwhelming weight of authority" required possession." However, it did not rest solely on this orthodox ground. Chief Justice Stone repeated his previous statements about judicial freedom to determine immunity in the absence of "recognition and allowance." But he added a significant qualificationthe exercise of this freedom must be in accord with executive policy. The "controlling" consideration in Hoffman, he declared, was that the State Department had not granted this claim, nor had it ever advocated immunity for vessels owned but not possessed by foreign governments. ${ }^{\text {it }}$ The Chief Justice said that " $[\mathrm{i}] \mathrm{t}$ is therefore not for the courts . . to allow an immunity on new grounds which the government has not seen fit to recognize." Fo For this would embarrass the political department in its efforts to secure the national interest, just as would denying immunity contrary to executive policy. ${ }^{50}$

On its face Hoffman would seem to advocate a somewhat inconsistent approach. Requiring courts to look to past executive policy in the absence of

48. The State Department's first "suggestion" merely stated that the Department was transmitting the Mexican Government's claim "as a matter of comity between the United States Government and the Government of Mexico for such consideration as this Court may deem necessary and proper." Mexico v. Hoffman, 143 F.2d 854, 855 (9th Cir. 1944). The second communication said that the Department accepted as true the assertion that the Mexican Government owned the libelled vessel. Miexico v. Hoffman, 324 U.S. 30, 32 (1945).

49. The district court's conclusions are set forth in the opinion on appeal. Mrevice v. Hoffman, 143 F.2d 854, 856 (9th Cir. 1944).

50. Ibid.

51. Mexico v. Hoffman, 324 U.S. 30, 38 (1945).

52. In The Navemar, 303 U.S. 68 (1938), the then Justice Stone said: "The Degartment of State having declined to act, the want of admiralty jurisdiction because of the alleged public status of the vessel and the right of the Spanish Government to demand possession of the vessel as owner if it so elected, were appropriate subjects for judicial inquiry upon proof of the matters alleged." Id. at 75.

In Ex Parte Peru, 318 U.S. 578 (1943), Chief Justice Stone said: "the distriet court, in the absence of recognition of the immunity by the Department of State, had authority to decide for itself whether all the requisites for such immunity existed-whether the ressel when seized was petitioner's, and was of a character entitling it to the immunity." Id. at $587-8$.

In Ifexico v. Hoffman, 324 U.S. 30 (1945), he repeated his Perts statement almost verbatim, but be added to the words "entitling it to the immunity" a new phrass- "in conformity to the principles accepted by the department of the government charged vith the conduct of our foreign relations." Id. at 35.

53. See the quotation from Mexico v. Hoffman, supra note $\mathbf{5 2}$.

54. Mexico v. Hoffman, 324 U.S. 30,38 (1945).

55. Id. at 35 .

56. Id. at 35-6. 
"recognition and allowance" would ignore the importance of executive failure to approve the claim in the case at bar: If the State Department has favored immunity in similar situations and has declined to do so in this case, its disapproval of the instant claim could not be more clear. ${ }^{57}$ It would seem foolish for the courts to disregard present policy in favor of past policy.

Lower court decisions since Hoffman have avoided this inconsistency by refusing to acknowledge Hoffman as going beyond Pertl. ${ }^{\text {ss }}$ In the absence of "recognition and allowance," they have decided the immunity issue according to traditional principles without attributing significance either to present executive inaction or to past executive policy. ${ }^{50}$ But such a view ignores the Court's emphasis upon the absence of State Department approval. Even commentators who strongly disagree with the idea of political determination of immunity ${ }^{60}$ share the view that "... one reading the opinion of Chief Justice Stone in the Hoffman case might well assume that this is a subject with regard to which no body of law exists, a subject governed entirely by political considerations." 61

57. The Hoffman opinion contemplates contacting the State Department in all cascs. Where the foreign state presents its claim of immunity by appearing in court without requesting State Department aid, "the court will inquire whether the ground of immunity is one which it is the established policy of the department to recognize." $I d$. at 36 .

58. Upon executive "recognition and allowance," lower courts have generally granted immunity without further inquiry. See, e.g., Lorina v. The Rossia, (Civil No. 18767, E.D.N.Y., April 6, 1948) (complaint dismissed without opinion); Isbrandtsen Co. V. Netherlands East Indies Government, 75 F. Supp. 48 (S.D.N.Y. 1947). And exceutive approval of immunity has been held binding in cases where immunity would not have beel granted under traditional doctrine. See, e.g., Mexico v. Schmuck, 293 N.Y. 264,56 N.E.2d 577 (1944), reaff'd, 294 N.Y. 265, 62 N.E.2d 64 (1945) (government corporation) ; Stone Engineering Co. v. Petroleos Mexicanos, 352 Pa. 12, 42 A.2d 57 (1945) (same). Occasionally, a maverick court refuses to be bound, at least verbally, by "recognition and allowance." But in such cases immunity has been granted on traditional grounds. See, c.g., Frazer v. Hanover Bank, 119 N.Y.S.2d 319 (Sup. Ct.), aff'd, 281 App. Div. 861, 119 N.Y.S.2d 918 (1st Dep't 1953).

59. See, e.g., In re Investigation of World Arrangements, 13 F.R.D. 280 (D.D.C. 1952); Mexico v. Schmuck, 293 N.Y. 264, 56 N.E.2d 577 (1944), reaff'd, 294 N.Y. 265, 62 N.E.2d 64 (1945) (court held that it was free to decide all questions which the State Department had not "recognized and allowed"); Koster v. Banco Minero de Bolivia, 129 N.Y.L.J. 1590, col. 1 (Sup. Ct. May 12, 1953). But see The Beaton Park, 65 F. Supp. 211 (N.D. Wash. 1946), where the district judge made executive refusal to approve immunity for a Canadian ship an alternative ground for denying immunity, citing Mexico v. Hoffman.

60. E.g., Briggs, Law of Natrons 450 (2d ed. 1952); Deák, The Plea of Sovcreign Immunity and the New York Court of Appeals, 40 CoL. L. Rev. 453, 460-1. (1940); Jessup, Has the Supreme Cont Abdicated One of Its Functions?, 40 AM. J. INT'L L. 168 (1946). These writers maintain that immunity is a question for the courts to decide according to international law. The State Department, if it intervenes at all, should simply transmit the foreign government's claim of immunity and certify that government as a recognized sovereign.

61. Jessup, supra note 60 , at 168. See Briggs, Law of Nations 450 (2d ed. 1952). Cf. Deák, supra note 60, at 460 . 
A third interpretation makes Hoffman stand for the obverse of the "recognition and allowance" doctrine. It has been suggested that courts might be required to assume jurisdiction over the merits in each case in which the executive fails to "recognize and allow" immunity. ${ }^{62}$ This view looks to the concurring opinion of Justice Frankfurter for aid in interpreting the ambiguous statement of the majority. This concurrence, in which Justice Black joined, stated that courts should not surrender jurisdiction unless the State Department or Congress explicitly asserts the necessity of abstention. ${ }^{63}$ Such an interpretation seems more consistent with the majority position than do lower court opinions. And it provides a rational method for executive-judicial cooperation with respect to an essentially "political" question. ${ }^{\text {ot }}$

Because both the first and third interpretations of Hoffman would permit the executive to impose its views on the courts in all sovereign immunity cases, opponents of the absolute theory find hope in this decision. ${ }^{\circ 5}$ For the State Department has not shared the judiciary's determined adherence to the absolute theory. ${ }^{66}$

62. Cardozo, Socercign Immunty: The Plaintiff Descress A Day in Cours, 67 Harv. L. REV. 608,616 (1954).

This seems to be the State Department's interpretation of Hoffman. Sce 26 Der'T State Bulz. 984, 985 (1952), where its Acting Legal Advisor said in thinly veiled terms: "It is realized that a shift in policy by the exceutive cannot control the courts but it is felt that the courts are less likely to allow a plea of sovereign immunity where the esecutive has declined to do so."

63. Míxico v. Hoffman, 324 U.S. 30, 41-2 (1945).

64. Professor Cardozo is one of the few who recognizes that granting immunity is a "political" task. "Whether a defendant is entitled to immunity as a sovervign depends ca the resolution of two issues: (1) is it considered a sovereign government? and (2) will the interests of foreign relations be furthered by relieving it from responding in cuurt? Although the ultimate decision will probably be looked upon as a precedent in the field called 'international law, neither of these issues is a question of law to be left to the crurts for decision. The first depends on the 'status' of the defendant, always recognized as a question for the political branch to decide. The second can be answered only by the agency charged with the conduct of foreign relations. ..." Cardozo, ssspra nute 62, at 617-15.

65. See, e.g., Lauterpacht, 28 BRir. Y.B. INT'L L. 220, 26S-70 (1951) ; Cardozo, sisfro note 62 .

66. The State Department advocated abandonment of the absolute theory as carly as 1918 when it took the view that government vessels engaged in commerce should not receive immunity. 2 Hackworte, Digest of International Law 429 (1941). And in 1927 when the Attorney-General brought an antitrust suit against the Deutsches Kalisyndikat Gesellschaft, an "organization created and controlled by the French Republic," the Department stated that "it has long been the view of the Department of State that agencis of foreign governments engaged in ordinary commercial transastions in the United States enjoy no privileges or immunities not appertaining to other foreign corpurations, ageneics, and individuals doing business here, and should conform to the laws of this country governing such transactions." 2 Id. at 481 . But judicial refusal to hecd its views in many cases caused the Department to return to the absolute theory. For an account of exscutive efforts to curb immunity, see $2 \mathrm{id}$. at $426 \mathrm{ct}$ siq. And for the Department's most recent stand, see note 67 infra and accompanying text. 


\section{The Restrictive Theory}

In May, 1952, the State Department announced its adoption of the "restrictive theory." 67 This rule attempts to distinguish between public or sovereign and private or commercial activities of a foreign state and denies immunity to the latter. ${ }^{68}$

The restrictive theory, however, is another inadequate means of coping with the problem of foreign sovereign immunity. Like previous attempts to confine the absolute theory, it is based on an unrealistic distinction-in this case that the sovereign is not sovereign when it participates in private pursuits. This is unacceptable in theory because the state always acts for the general purposes of the community. It cannot act for private purposes. ${ }^{60}$ The Supreme Court made this the basis for its decision in The Pesaro, ${ }^{70}$ where it granted immunity to a merchant vessel owned and possessed by a foreign state. ${ }^{71}$ Also, Congress has recognized no distinction between public and private acts with respect to the liability of the United States. ${ }^{72}$

67. 26 Dep't STAte Bull. 984 (1952). This policy announcement took the form of a letter from the Acting Legal Advisor of the State Department to the Attorncy-General.

As indicated in the Department's statement, many European and several other countries apply the restrictive theory, while the United States, Great Britain and the Commonwealth, Czechoslovakia, Estonia, and Poland apply "the classical or virtually absolute theory of sovereign immunity." Apparently, the law in other nations is in a state of flux. Ibid.

68. Ibid.

69. Professor Lauterpacht writes "it is no longer generally accepted that the cconomic activities of the state-such as state management of industry, state buying, and state selling-are necessarily of a purely 'private-law nature'; that they are jure gestionis; and that in engaging in them a state acts like a private person. In these and similar cases ostensibly removed from the normal field of its political and administrative activities, the state nevertheless acts as a public person for the general purposes of the community as a whole. This applies not only to states with a socialist economy where trading or management of industry have become a public function of the state. For the state always acts as a public person. It cannot act otherwise. In a real sense all acts jure gestionis are acts jure intperii." LaUterpacht, supra note 65, at 224. See also Fenwick, International Law 308 (3d ed. 1948) ; Fairman, Some Disputed Applications of the Principle of Statc Immtmity, 22 AM. J. INT'L L. 566, 569 et seq. (1928).

70. 271 U.S. $562(1.926)$.

71. The Court, speaking through Justice Van Devanter, said that "when, for the purpose of advancing the trade of its people or providing revenue for its treasury, a government acquires, mans and operates ships in the carrying trade, they are public ships in the same sense that war ships are. We know of no international usage which regards the maintenance and advancement of the economic welfare of a people in time of peace as any less a public purpose than the maintenance and training of a naval force." The Pesaro, 271 U.S. 562, 574 (1926). Professor Lauterpacht states that this is "a view which, probably, is not far removed from reality. ..." LAUTERPACET, supra note 65 , at 224. For a conclusion similar to that of the Supreme Court, see De Howorth v. S.S. India, [1921] So. Af. L. Rep. [C.P.D. III] 451.

72. The Tucker Act permits the United States to be sued in the Court of Claims upon "[A]11 claims founded upon the Constitution of the United States or any law of Congress ... or upon any contract ... or for damages, liquidated or unliquidated, in cases not 
And in practice it is very difficult to draw the line between sovereign and commercial endeavors. ${ }^{73}$ It is generally stated that a sovereign activity is one in which only the government may engage, while a commercial activity is one open to private persons. ${ }^{74}$ However, in some states private persons may pursue all but a few activities, while in others the economic sphere in which ordinary citizens may participate is severely limited. ${ }^{3}$ Should the public-private distinction be based upon the economic structure of the United States or upon that of the defendant state $?^{70}$ Should the situs of the alleged harm

sounding in tort. ..." And it grants concurrent jurisdiction tu federal district cuturts in cases involving not more than $\$ 10,000$. 24 ST.1T. 505 (1887), 28 L.S.C. $\$ \$ 41(20), 250(1)$ (1946). The Federal Tort Claims Act permits federal district cuurts to hear "any claim against the United States, for money only . . . on account of damage to or luss of proferty or on account of personal injury or death ... caused by the negligent ur wrungful act or omission of any employee of the Government while acting within the seope of his uffice or employment, under circumstances where the United States, if a private persun, woull be liable to the claimant for such damage, loss, injury or death in arcurdance with the law of the place where the act or omission accurred." 10 ST.IT. 843, 2S U.S.C. \$931(a) (1946), as amended, 62 STar. 983 (1948), 28 U.S.C. $\$ 2674$ (Supp. 1952). (This, of course, does not permit suits against the United States for such acts as iraud, deceit, or malicious prosecution by its employees.) The Public Vessels Act pruvides: "A litel in persusam in admiralty may be brought against the United States . . . for damages causcd by a fublic vessel of the United States. .." 43 Sr.r. 1112 (1925), 46 U.S.C. $\$ 781$ (1910). This statute was passed to complement the Suits in Almiralty Aet, which provided fur suits against United States merchant vessels. 41 ST.1T. 525 (1920), 46 U.S.C. $\$ \$ 741-52$ (1946).

73. Outside of the traditional sphere of military and diplomatic activities, there is little international agreement upon what constitutes a "surereign," as distinguished irum a "nonsovereign," activity. See cases cited in the H.unvand Resenren, 20 Ax. J. In:t' L. 451, 609 et seq. (Supp. 1932) ; Bishop, New United States Polisy Limitring Suarciann In:mmity, 47 A.r. J. Ixt' L. 93, 103 (1953). All commentators, including those vilo advocate the restrictive theory, admit that this is a task af exceptional dificulty. Sce, c.l., id. at 105; Cardozo, Sorerciga Immunity: The Plamtiff Descrias a Das is: Courl, $67 \mathrm{H}$.uns. L. Rev. 608 (1954) ; Fensterwald, Soarciyn Immunity and Searet State Trafinu, 63 Harv. L. REv. 614,624 (1950).

Even agreement within a single nation may be difficult to achieve. Sw In re Investigation of World Arrangements, 13 F.R.D. 280 (D.D.C. 1952), one of the few reported United States decisions since announcement of the restrictive theory. Despite State Department refusal to "recognize and allow" the claim to immunity of the Anglu-Iranian Oil Co., the district court granted immunity. It found that supplying oil to the Koyal Liavy and Air Force "is certainly a fundamental government function serving a public purfuse." $I d$. at 290. United States courts have found it difficult to drav the line letween "guvernmental" and "proprietary" functions of municipal corporations. Sce 6 MeQvius:, Mlv" NICTPAL CoRPoRltions $\$ \$ 2798,2850$ (2d ed. 1928). Sce also Xew lurl: v. United States, 326 U.S. 572, 583 (1916).

74. See Fensterwald, supra note 73, at 617; Fitzmaurice, Slate Immamity Fron Proceedings in Foreign Courts, 14 ERIT. Y.E. INTL L. 123 (1933).

75. See Bishop, stipra note 73, at 103 .

76. It would seem expedient to base the public-private distinction upen the esonomic structure of the defendant state in order to minimize the possibilities of friction with that state. But then application of the restrictive theory in American cuurts misht tail to re* duce significantly the number of instances in which immunity wuld he granted. For private persons play a lesser role in the economies of most states than they do in the Cunited 
be determinative as in private international law ?77 Moreover, whichever nation is looked to, the further problem arises of determining whether the transactions should be classified according to their nature or their purpose. ${ }^{78}$ The "nature" test would categorize all purchases of goods as "commercial," because private persons can purchase goods. ${ }^{79}$ On the other hand, the "purpose" test would grant immunity if the government bought army supplies, but probably not if it bought tobacco for public resale. ${ }^{80}$ No satisfactory criteria have been devised for dealing with the many subtleties of this doctrine. ${ }^{81}$

Furthermore, the restrictive theory cannot be a functional doctrine, in the sense of promoting the policy underlying immunity. Adherence to any "legal principle" prevents close correlation between the immunity granted and the policy of avoiding international friction. It is difficult to determine in advance the cases in which immunity will be important to relations with a foreign state. $^{82}$

States. These states would therefore have a broader definition of what constitutes a sovereign activity. See Fitzmaurice, supra note 74 , at 123.

77. For an evaluation of the territorial principle in private international law, sec Niboyet, Territoriality and Universal Recognition of Rules of Conflict of Lanes, 65 HaRv. L. REv. 582 (1952).

78. The Department of State's announcement adopting the restrictive theory gave no indication of the criteria to be used in distinguishing "public" from "private" statc activities. 26 Dep'T State Bull. 984 (1952).

79. See LAUTERPACht, 28 BRIT. Y.B. INT'L L. 220, 225 (1951), for discussion of the "nature" test as developed in WeISS, COMPETENCE ou L'INCOMPETENCE DeS TRIUUNAUX a L'Égard des États Étrangers (Hague Academy of Int'l Law, 1923); Bishop, supra note 73 , at 105 .

80. See Fensterwald, supra note 73, at 621 .

81. After reviewing judicial efforts to apply the restrictive theory in various states, Professor Lauterpacht expresses doubts "whether the uncertainty produced by their decisions, the inconsistencies, and the resulting absence of an ascertainable standard capable of general application ought to be perpetuated." LAUTERPACHT, supra note 79, at 225 . He points out that the French have abandoned the public-private distinction for the purpose of delimiting the competence of judicial and executive tribunals. Id. at 224. Compare this conclusion with Professor Bishop's optimism in discussing the State Department's adoption of the restrictive theory: "In dealing with the harder cases, it may be hoped that our courts, lawyers and government officials will pay close heed to the decisions and the reasoning of the courts in other countries which have been drawing this distinction for many years and which will continue to have occasion to do so. On the basis of stuch a comparative approach, and taking into account the internal-law distinctions which our own coutrts have drawn in the fields of municipal corporations' liabilities to suit and inter-governmental immunities from taxes, we may expect the new practice to work out more satisfactorily than could any present attempt to give it precision in words." Bishop, supra note 73, at 106.

82. See, e.g., In re Investigation of World Arrangements, 13 F.R.D. 280 (D.D.C. 1952), discussed in notes 33 and 73 supra. In that case immunity would have been denied the Anglo-Iranian Oil Co. under both the restrictive and the absolute theories. And the State Department did not "recognize and allow" the British Government's claim to immunity. Yet the district judge, apparently less bound by rules than the State Department, stressed immunity's importance to Great Britain in this instance and granted its request. 
Executive adherence to the restrictive theory overlooks the opportunity presented by the third interpretation of Hoffman. If judicial principles are to govern, there is little justification for removing the task of applying them from the courts. ${ }^{\$ 3}$ But the significance of the executive determination made possible by Hoffman is that it would permit case by case policy decisions on questions of immunity. Under this flexible approach, the executive would grant immunity whenever the exercise of judicial authority in the particular situation threatened to prejudice foreign relations. And immunity would be denied in all other instances. ${ }^{84}$

\section{The Unresolved Probleas of the Injured Party}

Yet executive predominance, whether used to apply a policy approach or the restrictive theory, fails to provide adequately for the injured party. Exeeutive determination of judicial jurisdiction leaves plaintiff more helpless than - ever. It makes possible an adverse decision on the question of immunity without assuring him of the hearing provided by prior practice. ${ }^{85}$ Upon "recognition and allowance," courts dismiss plaintiff's suit. ${ }^{80}$ Such an administrative determination without notice and hearing seems inconsistent with the spirit of due process. ${ }^{\mathrm{st}}$

And even if procedures were established for a hearing before the State Department, ${ }^{s s}$ this would not aid the plaintiff in cases where immunity is granted.

83. One commentator has attempted to justify executive determination by stating that: "So long as the Erecutive ... acts by reference nut to shiting motives of palisy but to considerations of legal principle, there is roum for the view that utestions of immunity are a technical legal matter of some complexity; that the relevent Department of the Executive which, with the help of an expert staff fully trained in this liranch of the law, addresses the Court on this subject is particularly well-equipfel fur arswering the questions involved in accordance with international law: and that unless there is an assurance that courts will show sufficient familiarity with the rules of international law en the suiject ... there is no reason to view the existing practice with undue apprehensinn." Lyons, The Conclusizeness of the 'Suggestion' and Certificate of the American State Defartment, 24 BRIT. Y.B. INT'L L. 116, 146-7 (1947).

84. This would avoid the absurd results reached in the cases cited note 37 sufra.

85. Procedure under the doctrine of "recognition and alluwance" laid down in The Nazemar is in sharp contrast to the traditional court trial on the issue of immunity. The State Department may grant immunity before the plaintiff has any idea that it has been requested. Cardozo, Sorcreign Immunity: The Plaintiff Descries A Day in Court, 67 HaRv. L. Rev. 698, 613 (1954).

86. See, e.g., Ex Partc Peru, 318 U.S. 57 (1943); Isbrandtsen Ca. v. Xethurlands East Indies Government, 75 F. Supp. 48 (S.D.N.Y. 1947); Piascils v. British Ministry of War Transport, 54 F. Supp. 487 (S.D.N.Y. 1943).

87. Some commentators have even raised the question uf the constitutionality of such a proceeding. E.g., Cardozo, supra note 85, at 613; Kulm, The Extension of Suzcrcignt Inhmunty to Government-Owned Connercial Corporations, 39 A.r. J. I::riL L. 772,775 (1945); Lyons, sitrra note \$3, at 141.

88. It has been suggested that the requirements of due press weuld lis nut by allww: ing plaintiff either oral or written argument before the State Departmcnt. Carduzy, sufru note 85 , at 617 . If the Department acts on a case to case basis, geared to the demands oi 
The day in court which plaintiff deserves is not one for a sterile struggle over his right to sue. $\mathrm{He}$ is entitled to a hearing on the merits of his claim. ${ }^{80}$ From plaintiff's viewpoint, it makes no difference whether this opportunity for relief is denied by the courts or by the executive. Nor is it consolation that the decision is made according to a policy approach or the restrictive theory rather than the absolute theory.00 The vice of immunity is always the same-it is the permanent refusal to hear an injured party's complaint when it is doubtful that he will be otherwise compensated. ${ }^{91}$

The injustice of allowing immunity is particularly apparent in tort cases. A private party who makes a contract with a foreign government enters into the transaction voluntarily. Although his bargaining position may not be equal to that of the contracting government, nevertheless he can often protect himself against breach by obtaining security. Or the terms of the bargain may reflect the element of risk, as in a foreign bond investment. But the situation is generally quite different with respect to one whose person or property is tortiously damaged by a foreign sovereign. He seldom incurs the risk of injury voluntarily, and when he does, he usually cannot protect himself adequately.

Many foreign states recognize their liability before their own courts. ${ }^{02}$ And United States courts may entertain suits against the federal government in both contract and tort.93 But no corresponding reform of international law has taken place. ${ }^{94}$ Assuring redress to persons wronged by a foreign sover-

international relations, such a hearing would be of little value to the plaintiff. For the determination of immunity would then be a matter peculiarly within the Department's competence. And it is doubtful that plaintiff's argument would influence its conclusion. On the other hand, if the Department bases its decision on the restrictive theory or any other legal formula, a hearing would be important to plaintiff. But the suggested hearing would provide plaintiff with a less adequate opportunity to present his case than did the trial which he formerly enjoyed on the issue of immunity.

89. Some writers often appear less interested in increasing the number of cases in which courts may hear the merits than in preserving judicial power to determine the jurisdictional question. See the authorities cited note 60 supra.

90. Cf. Thomason v. United States, 184 F.2d 105, 108 (9th Cir. 1950), where the court noted that a distinction such as that between "public" and "merchant" vessels was "insignificant to the merits of the seaman's claim."

91. The injured party's alternative prospects for recovery against an unwilling sovereign defendant are indeed dim. Diplomatic adjustment of his claim is slow and uncertain. And suit against the foreign government in its own courts, if permitted, "would probably necessitate expenses incommensurate with the prospective recovery." Fensterwald, Sovereign Inmmunity and Soviet State Trading, 63 HARv. L. Rev. 614, 622-3 (1950). See also The Pesaro, 277 Fed. 473, 485 (S.D.N.Y. 1921), aff'd, 271 U.S. 562 (1926).

92. For brief discussion of the extent to which the leading trading states allow themselves to be sued at home, see LAUTERPACHT, 28 BRIT. Y.B. INT'L L. 220, 234-5 (1951); Sanborn, The Immunity of Merchant Vessels When Ozmed By Forcign Govermmonts, 1 ST. JонN's L. Rev. 5, 17-18 (1926).

93. See note 72 stipra.

94. Professor Lauterpacht has stated that: "there are but few subjects in which cco- 
eign without jeopardizing relations with that sovereign is a problem that remains to be solved.

\section{A Profosed Approach}

For acts within United States territory, a foreign government should enjoy no greater freedom from suit in United States courts ${ }^{95}$ than does the federal government. ${ }^{96}$ If a foreign state chooses to act within the United States, it seems not unfair to require it to abide by American policy as embodied in various statutes restricting immunity. ${ }^{97}$ Under this approach, liability for a British warship's tortious conduct in American waters would be determined by the Public Vessels Act. ${ }^{\text {as }}$ And where an asency of the Turlish Covernment breaches a contract made in the United States, it would le liable to suit

nomic and social factors and the general progression tastirds tite rule of low within tite state provide a more compelling opportunity for a resamination and eventusl remwal of

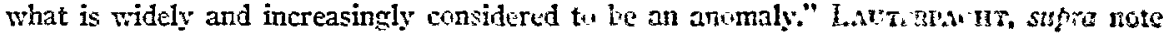
92, at 249. See also Iustice Frankifurter's suggetion that the duetrine of swercizn im-

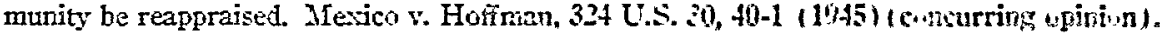

95. The appreach suggested by this commut purrorts th anply only in the fulural courts. Becanse foreign savereign immunity is a subject of yzuliarly national conesm, it is probable that national policy is controlling in state cuurts al o. Sce Nute, $45 \mathrm{CoL}$. $\mathrm{L}$. Rer. 80, 84 n.19 (1945). Certainly, state courts have generally followed the Supreme

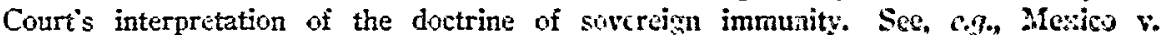
Schmuck, 293 N.Y. 264, 56 N.E.2d 577 (1944), redf'd, 294 N.Y. 265, 62 N.E.2d (st (1945): Stone Engineering Co. v. Petroleos Mexicanos, 352 Pa. 12, 42 A.2d 57 (1945). Desils, The Plea of Sozerciyn Inmminty and the New Forle Court of Apteals, 40 CoL L. Ker. 153, (1940). Yet, to avoid added complication and unnecessary ubjection, it appars wice to limit the proffered program to the fideral courts. This would nut detract from its efficacy. For plaintiffs, in order to gain the advantages of the refurm, would always sue in the federal courts, provided that cther jurisdictional reguiremonts could la mot.

96. This limitation upon foreign surercign immunity would reprecsnt no startling innovation. One of the early American decisivis granting immunity was hased upin the idea of assimilating the foreign state to the domestic state. Leng $v$. The Tampicu, 16 Fed. 491, 495 (S.D.X.Y. 1883). And a reecnt case remphasized this idea. "In the absence of statute or treaty, no sound principle of law or of international cumity requircs that the courts of this country treat a foreign government mure inworably as to swvereign immunity than our amn Government is treated by the courts." The Eeaton Park, 65 F. Sugp. 211, 212 (W.D. Wash 1946). See also L.atTERP.CHT, stipra note 92, at 22\%.

97. On the contrary, the unfairness lies in allowing the forcign state to remain above the local law wille the domestic state and all its citizens are subjcet to that law. This principle was recognized in Article 11 of the Harbaru Rromarar, 20 An. J. InT'L L. 451 (Supp. 1932), which proposed that: "A State may be made a respendent in a procesding in a court of another State when, in the territory of such other State, it engages in an industrial, commercial, financial or other business enterprise in which private forsuns may there engage. ..."Id. at 597. Reiorm based on the assimilation of the furcign state ty the local state seems in the offing. "Public opinion and practical consideratiuns du not permit too wide a gap between the law governing the immunities of the hume state ani the law, which many regard as increasingly artificial, unjust, and ardwis, redating to, the immurities of foreign states." L.1UTERr.1CHT, suthra nute 92, at 221.

98. 43 STAT. 1112 (1925), 46 U.S.C. \$7S1 (1946), quoted nute 72 surra. 
upon that contract because the Tucker Act grants a remedy against the federal government.99

For acts outside the United States, a foreign state should receive no greater privilege in American courts than it reserves for itself at home. ${ }^{100}$ If the act occurs within the defendant state, its interest in affairs within its own territory would seem to demand that its view of domestic sovereign immunity govern. ${ }^{101}$ Plaintiff would have no cause to complain. Having gone abroad, he cannot expect his rights to be determined according to American views. If the act occurs within a third state, that state could conceivably provide the standard for determining immunity. ${ }^{102}$ But its interest in this dispute would

99. See note 72 supra. This illustrates one of the minor modifications that may have to be made in assimilating the foreign state to the United States with respect to acts done by the former within our borders. The various statutes restricting the immunity of the United States before its own courts may contain provisions which would be inconsistent with full application of the suggested reform. For instance, the Tucker Act places an upper limit of $\$ 10,000$ on the recovery that may be had against the United States in federal district courts, while no such limit exists for suits in the Court of Claims. See note 72 supra. In order to provide adequate relief it would seem sensible not to apply this upper limit in destrict court cases involving contract claims against a foreign sovereign, unless the Court of Claims were to be made available to the plaintiff. The statute implementing the proposed reform could incorporate all such necessary modifications. See text at note 132 infra.

In cases where process cannot be served upon a foreign state through ordinary mcans, plaintiff should be permitted to serve the diplomatic representative of that state. Sce Article 19 of the HaRvard Research, sipra note 97, at 676, which suggests an analogous result via a more circuitous procedure.

100. See Sanborn, supra note 92, at 15-16. Cf. Mann, Sacrosanctity of Forcign Acts of State, 59 L.Q. REv. 42, 157 (1943). Many proposals for reform apply only to at foreign state's acts within the forum. E.g., Article 11 of the Harvard REsearcil, supra note 97, at 597. However, it is interesting to note that the State Department letter adopting the restrictive theory did not contain any such limitation. Bishop, Ncw United States Policy Limiting Sovereign Immunity, 47 AMr. J. INT'L L. 93, 106 n.41 (1953). Indeed, a proposal that did not curtail immunity for acts done outside the forum would fail to deal with many important situations.

Under this suggested approach, one injured by a French mail truck would gain access to American courts if France permits itself to be sued upon such a claim. And where a merchant ship operated by the Italian Government fails to deliver goods to their American purchaser, according to a contract made in Italy, it would be liable in American courts if liable in Italy.

But if the tribunal in which the foreign state grants a remedy is an administrative board or other body substantially different from our courts, the United States would decline jurisdiction, applying a doctrine similar to that of formm non convenicns in private international law.

101. Just as the territorial principle tips the balance in favor of adopting United States policy toward its own immunity as the standard for the immunity of a forcign government acting within the United States, here it favors adoption of the policy of the defendant state. See note 97 supra. The latter state, as both defendant and the situs of the event, would seem the more intimately concerned.

102. The lex loci actus is a solution widely followed in private international law cases. See Niboyet, Territoriality and Universal Recognition of Rules of Conflict of Lawe, 65 HARV. L. REv. 582 (1952). 
not merit preference over the views of either the defendant state or the forum. ${ }^{103}$ Here the standard of the defendant state should again prevail. Because the proposed over-all limitation of immunity would deprive the defendant state of its presently privileged position, it would seem expedient to ease its adoption in this instance ${ }^{104}$ by allowing the defendant state's conception of sovereign immunity to govern in United States courts.

In order to foster foreign friendship. flexible procedures may be necessary where this approach would deny immunity. These procedures would deal with the occasional cases where matters closely allied with sovereign prestige or security may be the subject of litigation. ${ }^{05}$ Whenever the State Department is persuaded that such a case is before the courts, it should request a continuance. ${ }^{106}$ And postponement for a reasonable time should then be mandatory. This will allow a foreign state that can foresee liability an opportunity to save face by disposing of its dispute through arbitration, diplomatic negotiation or other means of settlement. ${ }^{107}$ If plaintiff's claim remains unsatisfied at the expiration of the period, he should be able to proceed with his case unless the State Department can show cause for further postponement. Where settlement does not result from another continuance, the court should ordinarily hear the merits.

But the State Department should still be able to prevent the exercise of jurisdiction where it rould prejudice the national interest. In the rare tort cases where this might be necessary, ${ }^{108}$ upon State Department certification the United States should be added as defendant.109 The Department should

103. Here the territorial state is not one of the parties to the jurisdictional dispute; it is therefore less directly concerned with the question of immunity than either the defendant or the local state. However, if the decision on this preliminary, "public international law" question is against the defendant state, then the defentant is treated lilie a private person. In such a case, the principles of private international law govern, as in any other case involving foreign facts.

104. Where the defendant state's act takes place in the United States, international expediency should yield to American policy toward sovereign immunity. Sce note 97 stipra and accompanying text.

105. For instance, at least temporary immunity may be extremely important to a government that cannot meet payments to American bondholders. Or a decision affecting foreign exchange controls may threaten international relations. See Sullivan v. Sao Paulo, 122 F.2d 355 (2d Cir. 1941), discussed in note 36 sipra.

106. The same procedure which the Department emplays far ather communieativns with the courts would serve hare. See note 41 supra.

107. For example, this breathing spell would provide an opportunity for the firisncially embarrassed state to work out a plan satisfactory to creviturs.

10s. It is doubtful that foreign governments would press very viguruusly to alitain immunity in most tort cases. Compared to the amounts involved in contract cases, the damages for injury to plaintiff's person or property vould generally he small. And the injustice of denying plaintiff a remedy is apraront. See p. 116is strpa. For the roustio consequences to international relations of the suracted limitation of immunity, ste tast at notes 117-129 infra.

109. This, of course, would require Congressional legistution. Soe test at note 130 infra. 
then "recognize and allow" the foreign government's claim to immunity, and plaintiff should litigate his claim against the United States. If he wins his case, he should satisfy his judgment against the United States. It alone can distribute the loss among all who benefit from this protection of the national interest. Furthermore, it can better bear the burden of awaiting reimbursement through diplomatic channels than can plaintiff. In contract cases where foreign relations will be injured by the exercise of juriscliction, the State Department should simply "recognize and allow" immunity. Plaintiff should not recover from the United States in such cases. Having voluntarily undertaken the risk of dealing with a foreign sovereign, often in order to obtain great profits, he cannot expect other taxpayers to become insurers for his losses. ${ }^{\mathbf{1 1 0}}$

Similarly flexible treatment of the problem of execution against foreign sovereign property would assure relief to the successful plaintiff without sacrificing international harmony. ${ }^{111}$ When the foreign state posts bond to obtain release of its property, as is often done in an in rem proceeding, judgment can be satisfied out of the bond.112 And it seems probable that in most other cases a sovereign will honor a judgment, either because of a desire for reciprocal treatment for its nationals or because of respect for public opinion. ${ }^{113}$ However, if defendant fails to satisfy judgment within a reasonable time, plaintiff should request a court order levying upon any sovereign property within the jurisdiction, ${ }^{114}$ with the exception of diplomatic, military, and similar prop-

110. Of course, the dividing line between the traditional categories of tort and contract is far from precise in the variety of situations possible in an international context. It may be that in some "contract" situations the plaintiff's participation is sufficiently involuntary, his bargaining position sufficiently weak, and his profit prospect sufficiently limited to justify treating him as a tort victim.

111. Because of judicial adherence to the absolute theury of jurisdictional immunity in the United States, there have been few occasions for considering the problem of execution against foreign sovereign property. In the only case of note, the Second circuit held that execution could not issue against sovereign property even where the sovercign had consented to the suit in which the judgment against him was rendered. Dester \& Carpenter v. Kunglig, 43 F.2d 705 (2d Cir. 1930), cert. denicd, 282 U.S. 896 (1931). Although many writers and foreign courts agree with this decision, it is not certain that immunity from execution is a generally acknowledged principle of international law. LAUTERPACHT, 28 BRIT. Y.B. INT'L L. 220, 222 (1951). And sentiment against such immunity has been increasing. See, e.g., Fensterwald, Sovcreign Immmity and Sozict Stalc Trading, 63 HARv. L. Rev. 614, 626 (1950); LAUTERPACHT, supra at 222.

112. This appears to be usual in admiralty proceedings. See, c.g., lix larle Pert, 318 U.S. 578, 580 (1943), where Justice Frankfurter points out in his dissent that "the actual stake of the controversy is a bond." $I d$. at 601 .

Article 24 of the Harvard Researci, 26 Am. J. INT'L L. 451, 714 (Supp. 1932), would extend this practice to all sovereign immunity cases at the option of the defendant. This would avoid friction that might arise from execution against sovereign property, and it would also guarantee satisfaction to the plaintiff.

113. A few years after the decision in Dexter \& Carpenter v. Kunglig, 43 F.2d 705 (2d Cir. 1930), cert. denied, 282 U.S. 896 (1931), discussed note 111 supra, the Swedish Government paid $\$ 150,000$ in settlement of the judgment against it for $\$ 411,203.72$.

114. Requiring plaintiff to wait a reasonable time after judgment and then $t$ " go to court to obtain an order of execution represents a departure from fcderal practice. A 
erty. ${ }^{115}$ And in the absence of executive objection, the court should enforce the judgment. But the State Department should be able to prevent execution if it would be harmful to the national interest. The United States should then indemnify plaintiff for the amount that he would otherwise have recovered, instead of requiring him to subsidize the maintenance of international amity. ${ }^{118}$

\section{Effect on Forcign Relations}

Having provided for cases where immunity from the jurisdiction or from execution may be vital, no other considerations should detract from the proposed reform. Sovereign immunity is not an immutable principle of international law. ${ }^{117}$ The only doctrinal limitation upon the right of the loeal state to subject sovereign instrumentalities to its tribunals is that it give unambiguous notice of its intention to pursue such a policy in the future. ${ }^{118}$ The only practical limitation is the possibility of retaliation. ${ }^{110}$ But it is unlikely that this retaliation would amount to more than reciprocal treatment of the United States in foreign courts. 120

Judicial fear of offending sovereign dignity seems greatly exaggerated.1:1 Indeed, dignity would appear to require the modern democratic state to refrain

successful plaintiff may usually take out execution upon registering his judgment. The suggested innovation would prevent diplomatic difficulties that night athervise arise from a levy upon sovereign property. For the court would always contact the State Department before acting upon the request for execution. See Article 25 of the Harward Researcu, sufpra note 112, at 715-16.

115. For views approving of execution subject to these exceptions, see Fensterwald, supra note 111, at 626; LAUTERP.icet, supra note 111, at 243. The Hanwing Researsa, supra note 112, at 706, would allow execution arainst immubable property not uscd for diplomatic purposes and against property used in business enterprises.

116. See LAUTERPACHT, supra note 111 , at 243 . For purroses of strengthening its legal position in subsequent diplomatic negotiations with the defendant state, the United States might obtain an assignment of the judgment claim against that state.

117. For detailed support for this unorthodos conclusion, see LAvienpacns, supra note 111 , at 226 et scq.

11S. See The Exchange, 7 Cranch 116, 146 (U.S. 1S12), discussed in the test at note 5 supra; The Santissima Trinidad, 7 Wheat. 2\$3, 352-3 (U.S. 1822).

119. See Deak, The Plea of Sovereign Immunity and the New Yorl Court of Appeals, 40 CoL. L. REv. 453, 464 (1940). It is this prospect of retaliation that provides the real sanction of international law.

120. When a state believes that action taken against it by another state contravenes accepted usages and when it decides to retaliate, such retaliation is generally in lind. Sec, e.g., 22 DEP'T STATE BULL. 921 (1950) (the United States retaliated against restrictions imposed upon its official personnel by the Rumanian Government by imnosing similar restrictions upon Rumanian personnel in this country). And the importance of the United States in the world power process would seem to preclude foreign states from going beyond the bounds of reciprocal treatment. See Note, 5S Y.ALE L.J. 176, 180 (1948).

Such reciprocal treatment for the United States abroad is prceisely wint is cnvisaged by the suggested reform. See note 133 infra and accompanying text.

121. The decline of personal sovereignty in the modern world has made concern over sovereign dignity unrealistic. This has deprived foreign sovereign immunity of its usual 
from hiding behind its medieval shield. ${ }^{122}$ Adoption of the restrictive theory by many foreign courts, ${ }^{123}$ with occasional exercise of authority over acts of considerable public importance, ${ }^{124}$ has given rise to little protest. ${ }^{125}$ And American diplomatic relations suffered no adverse effects when, despite vigorous claims of immunity, United States courts excepted corporations of foreign governments from the absolute theory. ${ }^{126}$

Furthermore, from a long-term perspective, judicial remedies against foreign states may enhance, rather than impede, international friendship. ${ }^{127}$ Satisfaction of many otherwise frustrated claims would produce a favorable impact upon American opinion of other nations. And the envisaged reciprocal treatment of our government in foreign courts ${ }^{128}$ wothld yield a similarly beneficial result in terms of foreign opinion of the United States. This extended competence of national courts would also relieve diplomacy of the burden of attempting to settle many cases which the judiciary can handle more economically and more justly. ${ }^{129}$

justification. See note 4 supra and accompanying text. Most writers have reached this conclusion. See, e.g., Fensterwald, supra note 111, at 623; Sanborn, The Immmity of Government-Ozened Merchant Vessels, 39 AM. J. INT'z L. 794, 795 (1945).

122. See the opinion of Maugham, L.J., in The Cristina, [1938] A.C. 485, 521. And several centuries ago Baron Atkyns stated that: "the party ought in this case to be rclieved against the King, because the King is the fountain and hend of justice and equity; and it shall not be presumed, that he will be defective in either. And it would derogate from the King's honour to imagine, that what is equity against a common person, should not be equity against him. ..." Pawlett v. Attorney-General, [1668] Hard. 465, 469. And for the view that it would be inconsistent with the dignity of the local sovereign not to be able to exercise authority over a foreign governmental instrumentality operating within ity borders, see Mrolina v. Comision Reguladora, 91 N.J.L. 382, 390, 103 Atl. 397, 400 (Sup. Ct. 1918).

123. See note 67 supra.

124. See cases cited in Lauterpacht, 28 BRIt. Y.B. INt'L L. 220, 250 ct scq. (1951).

125. See LAUTERPACHT, supra note 124 , at 227 . No scrious diplomatic complications have arisen from exercise of jurisdiction over a foreign state, and the ancient fear of a casus belli is most unrealistic. Fachiri, Recognition of Foreign Lanes by Municipal Courts, 12 Brit. Y.B. InT'L L. 95 (1931); Note, 50 Yale L.J. 1088, 1089 (1941).

126. See cases cited note 31 supra.

127. It has often been recognized that many advantages would accrue to world trade if courts could hear the merits of commercial claims against foreign sovercigns. Sce, c.g., Fensterwald, Sovereign Immunity and Soviet State Trading, 63 Harv. L. Rev. 614, 627 (1950) ; the Pesaro, 277 Fed. 473, 481 (S.D.N.Y. 1921), aff'd, 271 U.S. 562 (1926). But morc rarely is there recognition of the broader, non-economic benefits that would result from judicial remedies for all claims against foreign states. See Lauterpacut, sttpra note 124, at 240 .

128. See note 120 supra and accompanying text; and see note 133 infra and accompanying text.

129. "On general principles it is desirable that, so far as possible, controversies of a judicial nature with foreign governments, whoever or whatever may be the opposing party, should be submitted to a decision of the courts of the land where jurisdiction would ordinarily lie. It is undesirable, where it can be avoided, that private claims of at judicial 


\section{Implementation}

A statute is essential to the full implementation of this program in view of its provision for liability of the United States under circumscribed circumstances ${ }^{130}$ and its procedural ${ }^{131}$ and other modifications. ${ }^{132}$ Legislation would also have the advantage, as compared with executive or judicial action, of constituting a relatively permanent pronouncement of American intention to extend its exercise of jurisdiction. The statute might express the willingness of the United States to recognize liability to a similar extent in foreign courts. ${ }^{133}$

Basic features of the proposed reform can be achieved even without Congressional action. The State Department can announce adoption of the program in the way that it announced the "restrictive theory."104 And it can communicate to foreign powers American readiness to accept reciprocal treatment. Although the United States cannot be made a party to a suit without statutory authorization, under the third interpretation of Hoff $m a n,{ }^{135}$ the Department can at least confine the judicial bent for granting immunity to situations where serious damage to foreign relations would occur. And before "recognizing and allowing" immunity in such situations, it can attempt to settle plaintiff's claim by obtaining a continuance.

The courts themselves can seize the initiative. Contrary to the views of

character, against a foreign government, should be pressed for settlement through diplomatic channels. The two governments who thus hecome partics to the controversy are often not equal antagonists. The arguments advanced on either side are seldom free from considerations that have no proper relation to the legal merits of the particular controversy. The weaker Power is often at a disadvantage in discussing such claims with a powerful sister nation whose good will it is important, for cther reasons, to preserve unruffed. What should only be considered as an argument may sometimes assume the appearance of an ultimatum. Secret collateral and personal considerations often become involved, especially when the advocates of private interests, acting indenendently, are in a position to supplement the government's representation of their client's claim by whatever ways and means may seem to them most properly adapted to that end." Brinton, Stits Against Fareign States, 25 Axr. J. Ixí L. 50, 62 (1931).

It is not improbable that Chief Justice Stone was referring to these less immediate implications when he stated that it would be detrimental to the national interest for the courts to decline jurisdiction without executive approval. See test at note 56 supro.

130. See p. 1167-S supra; see also text at note 116 supra.

131. See notes 109 and 114 sitrira and accompanying text.

132. Eee notes 99 and 100 stipra. Legisiation would, of course, eliminate the reluetance which courts have shown to curb the granting of immunity in the alecnce of Congressional mandate. E.g., The Pesaro, 271 U.S. 562, 574 (1026). And it would relieve the State Department from having to intuence judicial adogtion of a ncw arproach to immunity without giving the appearance of doing so. Sce, c.l\%, the Degartmont's annuuncement of the restrictive theory, partially quoted note 62 sispo.

133. Incorporation in such a statute of the United States' readiness to accept reciprocal treatment before foreign courts would assure other nations that American action does not stem from narrow nationalism.

134. See note 67 sipra.

135. See text at note 47 supra. 
pessimistic commentators ${ }^{136}$ and judges, ${ }^{137}$ courts are not bound to apply outworn doctrines until emancipated by legislation or by a long-overdue international convention. ${ }^{138}$ International law is no more static than other law..$^{130}$ Since the present immunity doctrines are of its own making, the Supreme Court can alter them at its next opportunity by announcing prospective application of the suggested policy.

\section{Conclusion}

The proposed statutory reform promises the fullest recognition of individual rights compatible with friendly foreign relations and community fairness. It grants relief for many otherwise unrequited wrongs, and it provides a method whereby every subsequent restriction of domestic sovereign immunity will produce a corresponding limitation of its international counterpart. The flexibility of this approach preserves the advantages of the third interpretation of Hoffman, leaving the State Department with responsibility for distinguishing between sensitive and unimportant situations. But when the executive intercedes, the plaintiff who most requires access to the courts-the tort victimis assured a judicial remedy. And even though one who contracts with foreign governments may occasionally be deprived of judicial recourse by "recoga nition and allowance," the proposed approach permits him to obtain judgment in many new instances. Furthermore, where diplomatic relations would suffer from enforcement of judgments obtained against foreign governments in either tort or contract, the United States as a whole pays the price of protecting the national interest.

136. See, e.g., Jessup and Deak, Dexter \& Carpenter, Inc. i' Kunglig Jarnwalstyrclsen et al, 25 A.r. J. InT'L L. 335 (1931). After discussing the Second Circuit's decision granting inmunity from execution to property of the Swedish Government, despite a valid judgment against that Government, the authors concluded that: "the results are regrettable and put the party who has a bona fide litigation with a foreign state under disadvantages which can hardly be reconciled with modern concepts of fairness and justicc. However, this anomalous situation cannot be remedied and full justice cannot be done in these cases until some international conventional agreement lets down the bars." $I d$. at 339. For a subsequent and less pessimistic view by Professor Jessup, see note 138 infro.

137. See, e.g., The Pesaro, 271 U.S. 562, 574 (1926); The Maipo, 259 Fcd. 367, 368 (S.D.N.Y. 1919).

138. Despite general agreement that the doctrine of foreign sovereign immunity should be modernized through international conventions, the only treaty attempting this has been the Brussels Convention of 1926 . But this only denied immunity to commercial vessels. Treaty Information Bull., No. 18 at 67 (U.S. Dep't State 1931); 3 Hudson, In'tekNational Legislation 1837 (1931). And the Uinited States has failed to acthere to this treaty.

As Professor Jessup has pointed out, in the absence of a multipartite convention, courts must continue to bear the burden of developing international law. Jessup, Has the Supr'mi' Court Abdicated One of Its Functions?, 40 AM. J. INT'L L. 168, 171-2 (1946).

139. In performing their function of creating and interpreting international law, courts must remain sensitive to changing community values. "International law . . . has at times, like the common law within states, a twilight existence during which it is hardly distinguishable from morality or justice, till at length the imprimatur of a court attests its jural quality.” Cardozo, J. in New Jersey v. Delaware, 291. U.S. 361, 383 (1934). 